\title{
A Comparative Study of the Verbal Analyses of the Case Laws of the Law Code of Hammurabi and the Book of the Covenant, Exodus 20-23
}

\author{
Babatunde Adekunle Ogunlana (PhD) \\ Baptist Theological Seminary, P.O. Box 94, Kaduna, Nigeria
}

\begin{abstract}
This paper considers the fact that the verbal forms typically used in the protases (if-clauses) of conditional sentences in the law code of Hammurabi (iptaras and iprus) have a typical value of past ('if a man stole a man's small child ...'), while the verbal forms typically used in the protases of conditional sentences in the Book of the Covenant (yiqțōl and wĕqātal) have a typical value of future ('if a man will steal another man ...'). Meanwhile, the verbal forms typically used in the apodoses (then-clauses) of conditional sentences in both $\mathrm{CoH}$ (iparras) and BC (yiqțol and wĕqātal) have a typical value of future ('... then he must be killed'). The conclusion of the research is that there are minor differences between the verbal forms in $\mathrm{CoH}$ and $\mathrm{BC}$. The differences seem to have to do with the perception of whether the crime is seen as already having taken place $(\mathrm{CoH})$ or to take place in the future $(\mathrm{BC})$.
\end{abstract}

Key Words: the Law Code of Hammurabi, the Book of the Covenant, Protasis, Apodosis

DOI: $10.7176 /$ JLLL/54-10

Publication date:March $31^{\text {st }} 2019$

\section{INTRODUCTION}

Akkadian (c.2000-1500 B.C.) and Biblical Hebrew (c.1000 B.C.- A.D. 70) are related Semitic languages and therefore have related verbal system. Their verbal systems are generally considered to be complex because their verbal forms are highly polysemous. The study of verbal systems is concerned with describing the verbal forms in a language in terms of the features of tense, aspect and modality. There is no straightforward method for interpreting these verbal forms (Joosten 39). Furthermore, the categorization of their verbal forms into tense, aspect and modality has been a difficult task. For instance, scholars first understood Biblical Hebrew as having tenses. Thus, many theories have been propounded in this regard. These theories are held by scholars like Gesenius, Blau, Rainey, Gropp and others. Tense has to do with the principle by which events are located in a given time-frame such as the past, the present or the future (Joosten 22). Later, scholars began to know about aspect-oriented theory, which emerged from Ewald's relative tense theory (Warren 64). They began to assert that Biblical Hebrew is a language with no tense, but with aspect (Hatav 2). Aspect is usually referred to the point of view from which a process is represented (Joosten 28). It is distinguished into two categories, the perfective and imperfective aspect. While the perfective aspect is defined as 'semantically punctual, complete, bounded, viewed from the outside' (Cohen, 'The Tense-Aspect System' 34), the imperfective aspect is 'semantically durative, incomplete, habitual, continuous, referring to a process, unbounded, viewed from the inside' (Cohen, 'The Tense-Aspect System' 34). Presently, the modality approach has been added to the circle. Modality has been understood by many scholars as the 'attitude or opinions' of the speaker towards an utterance (Cook, 'The Biblical Hebrew Verbal System' 64). There are many types of modality, but two of these are relevant for this work: epistemic modality and deontic modality. While epistemic modality has to do 'with the degree of knowledge regarding a process, as in expressions of doubt, likelihood, expectation or assertion', deontic modality has to do "with what makes a process a necessity as in expressions of intention, volition, permission or obligation' (Joosten 31). However, there is an overlapping in the three approaches. Warren argues that tense marking sometimes will often imply aspectual and modal functions. Aspect will tend to imply tense. Modal forms will also tend to imply aspect and tense (Warren 65-66).

In this study, I delve into solving a problem in relation to comparative study of the verbal systems of Akkadian in the law code of Hammurabi (c.900-500 B.C.) and Biblical Hebrew in the of case laws of Book of the Covenant (c.1792-1750 BC). Why do the protases of conditional sentences in the law code of Hammurabi $(\mathrm{CoH})$ have a typical value of past and the protases of conditional sentences in the Book of the Covenant (BC) have a typical value of future? And, why do the apodoses of conditional sentences in both $\mathrm{CoH}$ and $\mathrm{BC}$ have a typical value of future? I offer analyses of laws in $\mathrm{CoH}$ and $\mathrm{BC}$ in order to identify the verbal forms that appear in them, and then clarify the roles of these verbal forms. I then conclude by relating the roles of these verbal forms to the contexts of $\mathrm{CoH}$ and $\mathrm{BC}$. 


\section{ANALYSIS OF SOME LAWS IN COH}

I limit my analysis to 24 laws $^{1}$ in $\mathrm{CoH}$. And I restrict the study to main clause verbs. In these laws, there appear three finite verbal forms: iptaras, iprus and iparras These verbal forms appear in the protases and apodoses of conditional sentences in $\mathrm{CoH}$, and each of them functions differently in the laws. The statistical data of the verbal forms in $\mathrm{CoH}$ are represented in the table below.

\begin{tabular}{|c|c|c|}
\hline Verbal Form & Frequency & Percentage (\%) \\
\hline iptaras, 'he has decided' & 23 & 28 \\
\hline iprus, 'he decided' & 21 & 26 \\
\hline iparras, 'he will decide' & 37 & 46 \\
\hline Total & $\mathbf{8 1}$ & $\mathbf{1 0 0}$ \\
\hline
\end{tabular}

Iptaras

Iptaras (traditionally called perfect or T-perfect (Deutscher 31)) has a typical value of past, but with a specific nuance in meaning. The nuance is believed to be actuality. Through iptaras, the speaker represents the past event as still actual to the moment of speech (Kouwenberg 140). It is best rendered as 'someone has done something', 'something has happened' or 'something has been done' (Goetze 312, 321). It appears only in the protases of conditional sentences, and is identified as perfective aspect (Kouwenberg 94-95). It is most often used to express the conditional events in the protases. It occupies the 'foreground' or main line of the protases of the legal text. Any verbal form which occupies the 'foreground' of the text usually pushes the story or conversation forward. And any verbal form which occupies the 'background' provides some kind of background information which is critical to understanding the main story line (Witt 26). Of the 23 occurrences, 14 appear without the particle $-m a$, 'and', 7 appear in a chain of iprus-ma ... iptaras and 2 appear in iptaras-ma ... iptaras chain. When iptaras appears without the particle $-m a$, as in (1), it indicates that the event is completed at the moment referred to in the apodosis of conditional sentences (Cohen 127). This demonstrates that it expresses anteriority to the event described in the apodosis. It serves as a point of reference for apodictic clause (Loesov 89, 90). It also serves to indicate the current relevance of a past event. When we talk about the current relevance, we mean 'a present state resulting from a past action' (Loesov 85). ${ }^{2}$ This indicates that iptaras in the protases of CoH is 'present perfect', which contains the punishable acts.

\section{1. $\mathrm{CoH} 14$}

šumma awīlum mār awīlim șehram ištariq, iddâk. ${ }^{3}$

'if a man has stolen [iptaras] man's small child, he must be killed [iparras]'.

When iptaras appears in a chain of iptaras-ma ... iptaras, as in (2), it serves the same role as when it appears without the particle $-m a$ as described above. In addition, there is a logical relationship between the two clauses which contain iptaras, where the first clause is logically subordinate to the second.

\section{2. $\mathrm{CoH} 206$}

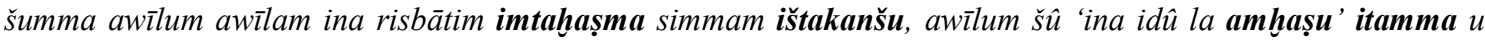
asâm ippal.

'if a man has struck [iptaras + ma] another man in a brawl and has injured him [iptaras], that man must solemnly declare [iparras], 'I did not wound [iprus] him intentionally.' It is he who must be responsible for the physician' [iparras].

But when iptaras appears in a chain of iprus-ma ... iptaras, as in (3), iprus normally forms the background for the more salient event, which occurs as iptaras. Iptaras thus represents the events that are legally the most

${ }^{1}$ I consider the laws which are closely paralleled to the casuistic laws in $\mathrm{BC}$, and they are $\mathrm{CoH} 8,14,21,57-58$, 117-119, 120-126, 195, 196-200, 206-208, 209-214 and 250-252.

${ }^{2}$ See also B. Comrie, Aspect: An Introduction to the Study of the Verbal Aspect and Related Problem. Cambridge, 1976 , p.56ff., $60 \mathrm{f}$.

${ }^{3}$ I follow the work of M.E.J. Richardson in my $\mathrm{CoH}$ transliteration and translation (see M.E.J. Richardson, Hammurabi's Law: Text, Translation and Glossary, London: T\&T Clark International, A Continuum Imprint, 2004) 
relevant (Cohen 127). ${ }^{4}$ So iptaras indicates the critical event, the event upon which the judgment in the apodosis is based (Huehnergard 157).

\section{3. $\mathrm{CoH} 250$}

šumma alpu, sūqam ina alākišsu awìlam ikkipma uštamīt dīnum š̂̀ rugummâm ul išu.

'if an ox while walking along the road gored [iprus+ ma] a man and has caused his death [iptaras], there must be no cause for complaint [verbless]'.

Iprus

Iprus (traditionally called preterite (Deutscher 31)) is thought to have a typical value of past. It refers to an action as a past fact, and is usually expressed as 'somebody did something' (Goetze 312). It is therefore normally translated with a simple past tense (Huehnergard 19). Iprus appears in the protases and apodoses of conditional sentences, and is identified as having perfective aspect. Of the 21 occurrences, 17 appear in the protases of conditional sentences and 4 in the apodoses of conditional sentences. In the protases, 7 appear without any particle, 9 appear with the particle $-m a$ and 1 appears with the subjunctive marker $-u$ (indicating subordinate clause). The four that appear in the apodoses are with the subjunctive marker $-u$. When iprus appears without any particle in the protasis, as in (4), it is used in the same sense as iptaras. It indicates the foregrounded event, the event upon which the judgment in the apodosis is based (Huehnergard 157).

\section{4. $\mathrm{CoH} 21$}

šumma awīlum bìtam ipluš, ina pani pilšim šuāti idukkūšuma ihallalūšsu.

If a man smashed [iprus] a way into a house, they must kill [iparras] and hang [iparras] him just where he broke in'.

When it appears with the particle - $m a$, as in (5), it expresses those facts which serve as 'background' leading up to the most important fact or facts that the lawmaker wishes to provide a legal remedy for in the apodosis (Maloney 277-280). So in this case, it depicts background activities as opposed to iptaras forms (Cohen 7). It denotes a situation that is anterior to the situation expressed by a verb in iptaras form (See Loesov 2004).

\section{5. $\mathrm{CoH} 209$}

šumma awīlum mārat awīlim im hașma ša libbiša uštaddī̌si, 10 šiqil kaspam ana ša libbiša išaqqal if a man struck [iprus + ma] the daughter of a man and has made [iptaras] her lose her unborn child, he must pay [iparras] ten shekels of silver for the foetus'.

When it appears with the subordination marker $-u$ in the protases and apodoses, as in (6) and (7), it serves as a referential event to an event previously mentioned in the protasis (Cohen, 2012:133).

\section{6. $\mathrm{CoH} 120$}

šumma awīlum se'ašu, ana našpakūtim ina bīt awīlum išspukma ina qarītim ibbûm ittabši u lu bēl bītim našpakam iptèma še'am ilqe, u lu še'am ša ina bītišsu iššapku ana gamrim ittakir, bēl še'im mahar ilim še'ašu ubârma bēl bìtim se'am ša ilqû uštašannāma ana bēl še'im inaddin

if a man stored [iprus] his grain into store in another man's storehouse and then a loss has occurred [iptaras] in the granary, or the owner opened [iprus] storehouse and took [iprus] the grain, or he has completely disagreed [iptaras] about the grain which was deposited [iprus $=\boldsymbol{u}$ ] in his house, the owner of the grain must declare [iparras] in the presence of the god the amount of grain, and the owner of the house must give [iparras] the owner of the grain must make double [iparras] the amount of grain he took.

\section{7. $\mathrm{CoH} 119$}

šumma awīlam e’iltum iṣbassuma amassu ša mārī uldušum ana kaspim ittadin, kasap tamkārum išqulu bēl amtim išaqqalma amassu ipatțar. 
if a man is gripped [iprus+ma] in poverty and has sold [iptaras] his slave-girl for silver after she has borne him sons, the slave-girl's owner may pay [iparras] back the silver the merchant loaned [iprus = u] and he must redeem [iparras] his slave-girl'.

Iparras

Iparras (traditionally called present-future or durative (Huehnergard 98)) has a typical value of future. But, it can also be used for present, durative and habitual actions as well as a range of modal meanings such as 'may', 'can', 'should' or 'must' (Deutscher 31). It is always posterior to a given reference point (which is the time of the law formulation) and since the future is close to modality, it can denote the latter in the legal apodosis (Cohen 127). It appears only in the apodoses of conditional sentences, and is identified as having imperfective aspect. It appears to signal foreground in the apodoses. Of the 37 occurrences, 3 appear without the particle $-m a$ and 4 appear with the particle $-m a$. When it appears without the particle $-m a$, as in (8), it serves to indicate anticipated information which depends on the validity of the protasis.

\section{8. $\mathrm{CoH} 198$}

šumma ìn muškēnim uhtappid u lu eșemti muškēnim ištebir, 1 mana kaspam išaqqal.

'if he has destroyed [iptaras] the sight of a working man or broken a bone of a working man, he must pay [iparras] one mana of silver'.

When we have a chain of iparras-ma ... iparras, as in (9), the first clause which has iparras-ma is logically related to the second clause with iparras (Huehnergard 50).

\section{9. $\mathrm{CoH} 206$}

šumma awīlum awīlam ina risbātim imtahaṣma simmam ištakanšu, awīlum šû 'ina idû la amhaṣu' itamma u asâm ippal.

'if a man has struck [iptaras] another man in a brawl and has injured him, that man must solemnly declare [iparras + ma], 'I did not wound him intentionally' and then he must pay [iparras] the physician'.

\section{Summary}

The three verbal forms iptaras, iprus and iparras in $\mathrm{CoH}$ are distributed, so as to express various events in the protases and apodoses of conditional sentences. Each plays different roles in CoH. Iptaras appears as a perfective aspect. It functions to express the critical and foregrounded conditional events in the protases. Iprus also appears as a perfective aspect. It is sometimes used in the same sense as iptaras. In addition, it is used to express background events in a chain of iprus-ma ... iptaras. It is also used to express referential events when it appears with the subordination marker - $u$. Iparras appears as an imperfective aspect. It serves to express the anticipatory consequences and signals foreground in the apodoses. The roles of these verbal forms are summarized in the table below:

\begin{tabular}{|l|r|}
\hline \multicolumn{1}{|c|}{ Category } & \multicolumn{1}{|c|}{ Verbal Form } \\
\hline Protasis: Conditional Events & 1. Iptaras - Primary foreground situation \\
& 2. Iprus - Secondary foreground situation, past \\
\hline Apodosis: Anticipatory Consequences & background situation and referential situation \\
& 1. Iparras - Primary foreground situation \\
\hline
\end{tabular}

ANALYSIS OF EXODUS 21:2-22:16

In Exodus 21:2-22:16, there appear three finite verbal forms: yiqțōl, wĕqātal and qātal and three non-finite

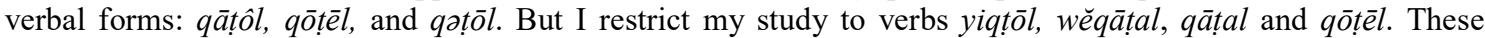
verbal forms appear in the protases and apodoses of conditional sentences in $\mathrm{BC}$, and each of them functions 
differently in the laws. The statistical data of the verbal forms in Exodus 21:2-22:16 are represented in the table below.

\begin{tabular}{|c|c|c|}
\hline Verb Form & Frequency & Percentage (\%) \\
\hline yiqtōl, 'he kills'/ 'he will kill' & 102 & 60 \\
\hline $\begin{array}{l}\text { wĕqātalal, 'and he kills'/ 'and he will } \\
\text { kill' }\end{array}$ & 44 & 26 \\
\hline qātal, 'he has killed' & 14 & 8 \\
\hline qōtẹel, 'he kills' & 10 & 6 \\
\hline Total & 170 & 100 \\
\hline
\end{tabular}

Yiqțōl

Yiqtōl (traditionally called prefix conjugation or imperfective (Joosten viii)) usually functions to refer to a process not yet begun (Joosten 268), to describe events belonging to the future (Driver 28), to express an action only as doing, and not as done, and to express a command (Driver 29). Joosten further stretches that over $80 \%$ of $y i q t \bar{c} l$ form in a typical text may have a future-modal function (Joosten 268). Yiqțol can appear as a 'long' yiqtōl and a 'short' yiqtōl. While the 'long' yiqtōl signifies the present-future or modal, the 'short' signifies usually jussive mood (Waltke and O’Connor 496).

Yiqtōl is the main tense and primary form in conditional sentences in BC, so it expresses the foreground situation in the laws. It is used to describe the conditional situations in the protases and the legal consequences in the apodoses. It has a typical value of future. It appears modally in the protases and apodoses. As a modal verb, it is used in the protases to denote propositions which are knowledge-based and are usually labeled epistemic (Hatav 116-117). It is used to express the speaker's attitude to the truth-value or factual status of the proposition in the protases (Palmer 8), as in (13). ${ }^{5}$

\section{Exodus $21: 2^{6}$}

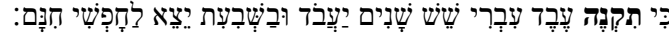
'When you buy [yiqtōl] a Hebrew slave, he shall serve six years, and in the seventh he shall go out free, for nothing'.

Also as a modal verb, it is used in the apodoses to denote directives which are not yet actualized and are usually labeled deontic (Palmer 8). Thus, its usage denotes the obligation, emanating from an external source (Palmer 9). The modal verb 'must', which, like other modal verbs, expresses the relation between the factual world and the nonfactual world, is often used for it (DeClerk 39). Furthermore, yiqtōol is used to represent a real situation which arises as a legal consequence of the situation described in the protasis (Waltke and O'Connor 511), as in (14). Sometimes, yiqtōl is used with qātôl to stress the condition or consequence of the laws, as in (15). ${ }^{8}$

11. Exodus $21: 34$

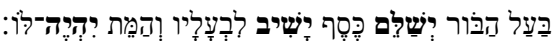
'the owner of the pit must make restoration [yiqtōl]. He must give [yiqtōl] money to its owner, and the dead beast must be [yiqtōl] his'.

12. Exodus 21:17

'Whoever curses his father or his mother must surely be put to death' [yiqtōl].

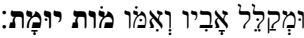

Wĕqāṭal

Wéqătal (traditionally called the suffix conjugation preceded by waw or perfect consecutive (Joosten viii)) is thought to have its origin in perfective qätal (see Waltke and O'Connor 521-523 and Joosten, 'Biblical Weqatal

${ }^{5}$ See also Exodus 21:4, 7, 9, 11, 18, 19, 20, 21, 22, 23, 26, 27, 28, 29, 30, 31, 32, 35, 37; 22:1, 4, 5, 6, 7, 9, 13.

${ }^{6}$ The Hebrew text used is the 'Masoretic Text' and my English text is based on the 'English Standard Version'.

${ }^{7}$ See also Exodus 21:2, 3, 7, 9, 10, 21, 26, 27, 29, 32, 34, 37; 22:3, 4, 6, 11, 12, $14,16$.

${ }^{8}$ See also Exodus $21: 5,12,15,19,20,22,28,36 ; 22: 2,3,5,11,12,13,15$. 
and Syriac hwa Qatel' 3). It also has a typical value of future. Furthermore, its semantics, according to Cook, are compatible with temporally successive expressions (Cook, 'The Semantics of Verbal Pragmatics' 265). He defines temporary succession as the 'the linear portrayal of events according to the order or their occurrence in the depicted world' (Cook, 'The Semantics of Verbal Pragmatics' 251). Wěqătal is the form of preference for expressing chronological sequence (Kompaoré 65). Joosten emphasizes that wěqātal and yiqtōl often occur in the same context, and when they occur side by side, it is hard to detect any temporal, modal or aspectual difference between these forms. They share exactly the same temporal-aspectual-modal functions. Both can be used as expressions of futurity-modality (Joosten 18-19). Furthermore, wěqățal is often used to continue other modal forms like imperatives, jussives and cohortatives in the protases (Holmstedt 137).

Wéqātal appears as a modal form in Exodus 21:2-22:16. It is used in the same sense as yiqțol. It is identified as an extension of the form's primary modal meanings in the protases and apodoses. Just like yiqtōl, it signals foreground situations in the protases and apodoses. In the protases, it has an epistemic sense. It is used to continue the description of the situation already introduced by yiqțol in the protases, as in (16). ${ }^{9}$ So it does not appear in the clause introduced by the particle אם or. It is used to express foregrounded, temporally successive situations in the protases (See Cook, 'The Semantics of Verbal Pragmatics' 264-269).

\section{Exodus 21:26}

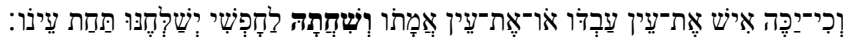
'When a man strikes the eye of his slave, male or female, and if he destroys [wĕqătal] it, he shall let the slave go free because of his eye'.

In the protases, it also appears as alternative situations, as in (17). ${ }^{10}$ It is especially used after participle to describe temporal or alternative situation in the protases.

14. Exodus 21:16

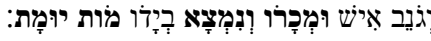

'Whoever steals a man and sells him [wĕqātal], or anyone found [wĕqātal] in possession of him, must die'.

From its frequent use in the apodoses, wĕqătal has a deontic sense. And it often marks temporal succession. Temporal succession refers 'to the order of their occurrence in the depicted world' (Cook, 'The Semantics of Verbal Pragmatics' 251). Wéqătal is always a continuation form, so never comes first in the chain. It also expresses a consequent (logical and/or chronological) situation to a situation represented by a protasis (Waltke and O'Connor, 1990:529). Waltke and O'Connor refer the relative waw in wĕqătal as apodosis waw, which is equivalent to English 'then'. This apodosis waw usually introduces an apodosis after a protasis (Waltke and O’Connor 521), as in (18). ${ }^{11}$

\section{Exodus 21:11}

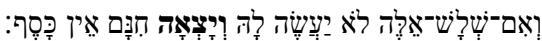
'And if he does not do these three things for her, then she shall go out [wĕqātall for nothing, without payment of money'.

Qāțal

Qātal (traditionally called perfective or suffix conjugation (Joosten viii)) is used to denote an action completed and finished at a definite moment in the past, fixed by the narrative (Driver 13). Qa attal has been translated with English as simple past, past perfect, present perfect, present, future perfect and modal (Cook, 'The Biblical Hebrew Verbal System' 75).

Qătal appears only in the protases in the text. In many instances, it has a typical value of past. It also refers to anterior situations (Hatav 147). Driver describes it as actions relating to a past time, which might have happened but did not happen, which are therefore only for the moment conceived as having occurred, under conditions not actually realized (Driver 23). Thus, its clauses refer to situations that precede the situations described in the

\footnotetext{
${ }^{9}$ See also Exodus 21:4, 12, 16, 18, 19, 20, 22, 26, 28, 29, 33, 35, 37; 22:1,5, 6, 9, 15.

${ }^{10}$ See also Exodus $21: 12 ; 22: 4$

${ }^{11}$ See also Exodus $21: 3,6,8,19,22,23,30 ; 22: 2,7,10$.
} 
protases. It is used to give background information to the laws. In such situation, it is used to express a completed action, as in (19). ${ }^{12}$

16. Exodus 21:8

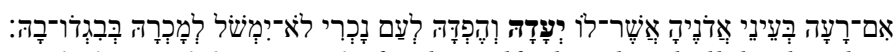
'If she does not please her master, who has designated her Iqätall for himself, then he shall let her be redeemed. He shall have no right to sell her to a foreign people, since he has broken faith with her'.

In few occasions, it is used in the same sense as yiqțol in describing propositional situations. It appears with in some occasions to express the propositional situation, as in (20)..$^{13}$

17. Exodus 22:2a (Eng. 3a)

'but if the sun has risen [qātal] on him, there shall be bloodguilt for him'.

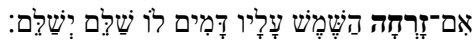

It also appears with in the protases. Sometimes introduces subcase of the main or subsidiary protasis (Wenham 98). In such case, או או seems to act like a waw-relative. Where is used instead of yiqtōol, as in (21). ${ }^{14}$

18. Exodus 21:37 (Eng. 22:1)

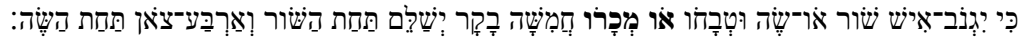

'If a man steals an ox or a sheep, and kills it or sells it [qätal], he shall repay five oxen for an ox, and four sheep for a sheep'.

Where there is a noun between $\mathrm{k}$ and the verb, yiqtōl is used, as in (22).

19. Exodus $21: 31$

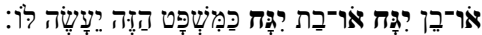
'Or if it gores [yiqtōl] a man's son or it gores [yiqtōl] a daughter, he shall be dealt with according to this same rule'.

Qōtẹel

Qōtēl is the Hebrew active participle. It is a verbal noun. It participates in both nominal and verbal characteristics. It has four principal functions in biblical Hebrew: it functions as a substantive, an adjective, a relative and a predicate (Waltke and O'Connor 613). As substantive, the qōtél functions as a noun, most often occurring with the definite article (Arnold 82). As adjective, it functions attributively (ascribes a quality to a noun) (Arnold 78) and predicatively (expresses an assertion about a noun or pronoun in a nominal clause) (Arnold 79). Qōtêl can be used as the equivalent of relative clauses. It is also used as the predicate of a verbless clause.

In Exodus 21:1-22:16, qōtēl is taken as equivalent to כי and finite verb in the protases of Exodus 21:12, 15, 16, 17. The finite verb expresses modality of necessity, as in (26). It has the same sense as yiqtol.

20. Exodus 21:17

'When a man curses [qōtềl] his father or his mother shall be put to death'.

\footnotetext{
${ }^{12}$ See also Exodus 21:5; 22:15.

${ }^{13}$ See also Exodus 22:2, 7.

${ }^{14}$ See also Exodus 21:36; 22:13.
} 
Summary

The four verbal forms yiqțōl, wĕqātal, qātal and qōtēll in Exodus 21:2-22:16 are distributed so as to express various situations in the protases and apodoses of casuistic laws. Each plays different roles in the text. Yiqtōl appears modally. It expresses the foreground situations in the protases and apodoses. It has an epistemic sense in the protases and a deontic sense in the apodoses. Wéqātal appears modally. It has the same sense as yiqtōl. In addition, it is often used to continue the description of the necessary conditional situations in the protases and obligatory consequent situations in the apodoses. Qātal appears as a perfective aspect and a modal verb. As a perfective aspect, it gives past background information to the laws. As a modal, it is used in the same sense as yiqțol. Qōtēel is used as modal and non-modal forms in modal clauses. As modal, it is used in the same sense as yiqtōl. As non-modal, it functions as an anticipated background situation. The summary of the functions of verbal forms in Exodus 21:1-22:16 is stated below:

\begin{tabular}{|c|c|}
\hline Category & Verbal Form \\
\hline Protasis: Necessary Propositions & $\begin{array}{l}\text { 1. Yiqț̄l-Primary foreground situation } \\
\text { 2. Wéqātal-Secondary foreground } \\
\text { situation } \\
\text { 3. Qātal-Secondary foreground situation } \\
\text { 4. Qātal-Past background situation } \\
\text { 5. Qōtēl-Secondary foreground situation }\end{array}$ \\
\hline Apodosis: Obligatory Directives & $\begin{array}{ll}\text { 1. } & \text { Qiqtāol-Primary foreground situation } \\
\text { 2. Wěqātal - Secondary foreground } \\
\text { situation }\end{array}$ \\
\hline
\end{tabular}

\section{CONCLUSION}

The roles of the verbal forms in $\mathrm{CoH}$ and $\mathrm{BC}$ and their implications for the contexts of $\mathrm{CoH}$ and $\mathrm{BC}$ are thus stated as follows:

- While iptaras and iprus are the main verbal forms in the protases of conditional sentences in $\mathrm{CoH}, y i q t \bar{o} l$ and wĕqătal are the main verbal forms in BC.

- While iptaras and iprus carry perfective aspect, appear indicatively, have a typical value of past and are used to express the conditional events, yiqț̄ol and wĕqātal carry modality, have a typical value of future and are used to express the necessary propositions in the protases of conditional sentences in $\mathrm{BC}$.

- While iparras is used as the main verbal form in the apodoses of conditional sentences in $\mathrm{CoH}$, and it carries imperfective aspect, appears indicatively, have a typical value of future and is used to express the anticipatory consequences in the apodoses, yiqț̄l and wĕqătal still remain the main verbs used in the apodoses of conditional sentences in $\mathrm{BC}$ and are used to express the obligatory consequences in the apodoses.

- Therefore, the verbal forms in $\mathrm{CoH}$ : iptaras, iprus and iparras being indicative and used in the modal clauses point to the fact that the laws in $\mathrm{CoH}$ were formulated based on the events that took place during the reign of Hammurabi, $\mathrm{CoH}$ must, thus, be read in the historical and political context of Hammurabi's long reign of 43 years. 
- Therefore, the verbal forms in BC: yiqtōl and wĕqătal being modal suggests that the laws in BC are Yahweh's propositions and directives for the Israelites. The propositions in the protases are knowledgebased because they are based on the events already known to the people. The directives in the apodoses are Yahweh's attitude towards the offenses described in the protases. BC must, thus, be a later insertion into the Sinai narrative context.

- Based on these findings, I submit that BC might have depended on a known legal code indirectly, however, its verbal system demonstrates that even if $\mathrm{BC}$ has depended on a known legal code, it has not been written using a strict direct syntactic correspondence.

- All the verbal forms in both $\mathrm{CoH}$ and the casuistic laws of $\mathrm{BC}$ are used to express the conditions in the protases and the legal consequences in the apodoses.

- Moreover, all of them being expressed in the conditional construction indicate that the verbal forms in $\mathrm{CoH}$ and $\mathrm{BC}$ are all equivalent in meaning, but belong to different categories.

- Iptaras and iprus which are the main verbal forms in the protases of conditional sentences in $\mathrm{CoH}$ carry perfective aspect, appear indicatively and have a typical value of past.

- In addition, iparras, the main verbal form, in the apodoses of conditional sentences in $\mathrm{CoH}$ carries imperfective aspect, appears indicatively and has a typical value of future.

- Yiqțōl and wĕqătal, the main verbal forms, in BC carry modality, appear modally and have a typical value of future.

- Therefore, the verbal forms in $\mathrm{CoH}$ : iptaras, iprus and iparras being indicative and used in the modal clauses point to the fact that the laws in $\mathrm{CoH}$ were formulated based on the events that took place during the reign of Hammurabi.

- Moreover, the verbal forms in $\mathrm{BC}$ : yiqțōl and wĕqāțal being modal suggests that the laws in $\mathrm{BC}$ are Yahweh's propositions and directives for the Israelites on Mount Sinai. The propositions in the protases are knowledge-based because they are based on the events already known to the people, and the directives in the apodoses are Yahweh's attitude towards the offenses described in the protases. The E-writers might have invented these verbal forms, which are different from the older law codes to fit the Sinai narrative context.

- The comparisons of the grammatical contexts of $\mathrm{CoH}$ and $\mathrm{BC}$ demonstrate that there are minor differences between the verbal forms in $\mathrm{CoH}$ and $\mathrm{BC}$. The differences seem to have to do with the perception of whether the crime is seen as already having taken place $(\mathrm{CoH})$ or to take place in the future (BC). 


\section{References}

Arnold, B. T. (2003). A Guide to Biblical Hebrew Syntax. New York, N.Y: Cambridge University Press.

Cohen, E. (2006). 'The Tense-Aspect System of the Old Babylonian Epic'. Zeitschrf. Assyriologie, 96, 31-68.

Cohen, E. (2012). Conditional Structures in Mesopotamian Old Babylonian. Winona Lake, Ind.: Eisenbrauns.

Cook, J. A. (2002). 'The Biblical Hebrew Verbal System: A Grammaticalization Approach', PhD Dissertation . University of Wisconsin-Madison.

Cook, John A. (2004). 'The Semantics of Verbal Pragmatics: Clarifying the Roles of Wayyiqtol and Weqatal in Biblical Hebrew Prose'. Journal of Semitic Studies, xlix/2, Autum.

Cook, John A. and R. D. Holmstedt. (2007). Ancient Hebrew: A Student Grammar. Draft Copy.

DeClerk, R. (2011). 'The Definition of Modality'. In Cognitive Approaches to Tense, Aspect, and Epistemic Modality (pp. 21-44). Amsterdam: John Benjamins Publishing Company.

Deutscher, G. (2000). Syntactic Change in Akkadian the Evolution of Sentential Complementation. Oxford; New York: Oxford Univ. Press.

Driver, S. R. (1892). A Treatise on the Use of the Tenses in Hebrew and Some Other Syntactical Questions. Oxford: Clarendon Press.

Goetze, A. (1936). 'The T-Form of the Old Babylonian Verb'. Journal of the American Oriental Society, 56(3), 297.

Hatav, G. (1997). The Semantic of Aspect and Modality: Evidence from English and Biblical Hebrew. Amsterdam: John Benjamins Publishing Company.

Holmstedt, R. D. (2002). The Relative Clause in Biblical Hebrew: A Linguistic Analysis. University of Wisconsin-Madison.

Huehnergard, J. (2011). A Grammar of Akkadian (Third Edition). Winona Lake, Indiana: Eisenbrauns.

Joosten, J. 'Biblical Weqatal and Syriac hwa Qatel Expressing Repetition in the Past'. Zeitschrift für Althebräisk, Vol. 5, Issue 1, 1992, pp.1-14.

Joosten, Jan. The Verbal System of Biblical Hebrew: A New Synthesis Elaborated on the Basis of Classical Prose. (Jerusalem Biblical Studies, Vol. 10). Jerusalem: Simor Ltd., 2012.

Kautsch, E. (1956). Gesenius' Hebrew Grammar. Oxford: The Clarendon Press.

Kompaoré, A. E. G. (2004). Discourse Analysis of Directive Texts: The Case of Biblical Law. Associated Mennonite Biblical Seminary.

Kouwenberg, N. J. C. (2010). The Akkadian Verb and Its Semitic Background. Winona Lake, IN: Eisenbrauns.

Loesov, S. (2004). 'T-Perfect in Old Babylonian: The Debate and a Thesis'. Babel \& Bibel, 1, 101-148.

Maloney, J. F. (1982). The t-Perfect in the Akkadian of Old Babylonian Letters, with a Supplement on Verbal Usage in the Code of Hammurapi and the Laws of Eshnunna. Harvard: Harvard University.

Palmer, F. R. (2001). Mood and Modality (2nd ed). Cambridge, UK ; New York: Cambridge University Press.

Ungnad, A. (1992). Akkadian Grammar. Atlanta, Ga: Scholars Press.

Waltke, B. K. (1990). An Introduction to Biblical Hebrew Syntax. Winona Lake, Ind: Eisenbrauns.

Warren, Andy. (1998). 'Modality, Reference and Speech Acts in the Psalms', PhD Dissertation. Cambridge University.

Wenham, G. J. (1971). 'Legal Forms in the Book of the Covenant'. Tyndale Bulletin 22, 92-102.

Witt, Andrew C. (2008). 'The Syntax of the Verb in Biblical Hebrew Poetry: The Linguistic Theory of Alviero Niccaci', Thesis. Southeastern Baptist Theological Seminary, Wake Forest, North Carolina. 